\title{
PENERAPAN PEMBELAJARAN KOOPERATIF MODEL NUMBER HEAD TOGETHER UNTUK MENINGKATKAN MOTIVASI DAN HASIL BELAJAR MATA KULIAH BAHASA INGGRIS
}

\author{
Aly Imron $^{1}$, Mujianto ${ }^{2}$, Yani Ratnawati ${ }^{3}$ \\ Jurusan Elektro, Politeknik Negeri Malang \\ mralyimron@polinema.ac.id, mudjianto@polinema.ac.id, yanirahma@polinema.ac.id
}

(Artikel diterima: November 2019, diterima untuk terbit: Desember 2019)

\begin{abstract}
Abstrak - Metode belajar mengajar Numbered Heads Together berhubungan dengan banyak siswa untuk memeriksa pemahaman siswa tentang materi ajar. Metode ini memiliki beberapa prosedur yang diterapkan secara eksplisit untuk memberikan waktu yang cukup untuk berpikir, menjawab, dan saling membantu antar anggota dalam kelompok dan diharapkan dalam proses pembelajaran dapat meningkatkan hasil belajar yang lebih baik. Tujuannya adalah untuk mengetahui peningkatan motivasi belajar siswa dan hasil belajar siswa melalui penerapan pembelajaran kooperatif metode Numbered Heads Together pada mata pelajaran bahasa Inggris. Penelitian eksperimental ini menggunakan rancangan Penelitian Tindakan Kelas dengan menerapkan pendekatan kualitatif serta dilaksanakan dalam dua siklus yang meliputi perencanaan, pelaksanaan tindakan, observasi, dan refleksi. Hasil perbandingan siswa antara siklus I dan siklus II signifikan dan meningkat tajam, artinya siklus II cukup baik dilihat dari motivasi belajar siswa yang terdiri dari Minat (57,33\%; 88)\%, Konsentrasi (62,67\%; 92\%), perhatian (56\%; 85,33\%), ketekunan (61,33\%; 87,33\%). Peningkatan rata-rata sebesar $26 \%$ dari siklus pertama ke siklus kedua.
\end{abstract}

Kata kunci: number head together, motivasi, classroom action research.

\section{Pendahuluan}

Motivasi belajar sebagian mahasiswa tergolong masih rendah. Hal ini dapat dikenali melalui 1) sebagian besar belum memiliki semangat tinggi dalam mengikuti kuliah, 2) perhatian belum maksimal, sering bermain dengan HP dan ngobrol di tengah pembelajaran sekalipun sesaat, 3) mendengarkan tapi tidak menulis. Kurikulum, tenaga pengajar, penggunaan strategi pembelajaran yang efektif, penggunaan media pembelajaran yang tepat, dan pelaksanaan tes untuk setiap tahapannya harus diterapkan dalam proses belajar mengajar. Kualifikasi nilai ditentukan minimal $\mathrm{B}$ atau skor $\mathbf{6 5}<\mathbf{N} \leq \mathbf{7 3}$ untuk mengetahui kemampuan hasil belajar mahasiswa. Apabila nilai hasil belajar mahasiswa kurang dari yang ditentukan yaitu minimal masuk kualifikasi B, maka yang bersangkutan harus melaksanakan remidi (tes perbaikan) sampai mahasiswa tersebut benar-benar menghasilkan nilai minimal. Berdasarkan data nilai mahasiswa teknik listrik berjumlah 25 orang diketahui bahwa sebanyak 12 orang tidak memenuhi kriteria ketuntasan minimum, sedangkan 13 mahasiswa yang lain tuntas. Rendahnya hasil belajar mahasiswa dapat disebabkan karena berbagai faktor. Faktorfaktor tersebut antara lain: rendahnya motivasi mahasiswa dalam belajar, kurang tepatnya pemilihan metode pembelajaran.

Dengan kata lain, rerata nilai bahasa Inggris mahasiswa Teknik Listrik berkisar pada skor nilai 60-70. Nilai skor ini apabila dikomulasikan sebesar $\mathrm{C}+$ atau $\mathrm{B}$. Hal ini belum cukup membanggakan mengingat bahasa sebagai alat komunikasi penting pada saat mereka nanti memasuki dunia kerja. Dengan penelitian ini diharapkan rerata skor bisa ditingkatkan yang berarti juga meningkatkan kemampuan bahasa Inggris mahasiswa.

Peneliti memilih metode pembelajaran Numbered Heads Together karena pembelajaran ini melibatkan lebih banyak mahasiswa dalam menelaah materi yang tercakup dalam suatu pembelajaran dan mengecek pemahaman mereka terhadap isi mata kuliah tersebut. Metode ini memiliki prosedur yang ditetapkan secara eksplisit untuk memberikan waktu lebih banyak untuk berpikir, menjawab, dan saling membantu antar anggota dalam satu kelompok dan diharapkan dalam pembelajaran yang dilakukan pada mahasiswa kelas II semester III akan mengalami peningkatan hasil belajar yang lebih baik.

Berdasarkan uraian di atas dan upaya untuk meningkatkan motivasi dan hasil belajar bahasa Inggris demi tercapainya proses pembelajaran yang lebih baik, maka dilakukan penelitian yang berjudul :

"Penerapan Pembelajaran Kooperatif Model Numbered Heads Together untuk Meningkatkan Motivasi dan Hasil Belajar belajar bahasa Inggris mahasiswa Polinema".

\section{KAJIAN PUSTAKA}

\section{A. Pembelajaran Kooperatif}

Menurut Suherman dkk (2003:260) Pembelajaran kooperatif mencakup suatu kelompok kecil mahasiswa yang bekerja sebagai sebuah tim untuk menyelesikan sebuah masalah, menyelesaikan suatu tugas atau mengerjakan sesuatu untuk mencapai tujuan bersama lainnya. Tidaklah cukup menunjukkan sebuah pembelajaran kooperatif jika para mahasiswa duduk bersama didalam kelompokkelompok kecil tetapi menyelesaikan masalah secara sendiri-sendiri. Bukanlah pembelajaran kooperatif jika para mahasiswa duduk bersama dalam kelompok-kelompok kecil dan mempersilahkan salah seorang diantaranya untuk menyelesaikan seluruh pekerjaan kelompok. Pembelajaran kooperatif menekankan pada kehadiran teman sebaya yang berinteraksi antar sesamanya sebagai sebuah tim dalam menyelesaikan atau membahas suatu masalah atau tugas. 


\section{B. Pembelajaran Kooperatif Metode Numbered Heads Together (NHT)}

Numbered Heads Together (NHT) merupakan salah satu jenis pembelajaran kooperatif yang tergolong dalam metode struktural. Metode struktural merupakan metode yang dikembangkan oleh Spencer Kagan dan kawan-kawannya. Meskipun mempunyai kesamaan dengan metode lainnya, metode struktural menekankan pada stuktur-struktur khusus yang dirancang untuk mempengaruhi pola-pola interaksi mahasiswa. Strukturstruktur Kagan menghendaki agar para mahasiswa bekerja sama saling ketergantungan pada kelompok-kelompok kecil secara kooperatif. Ada struktur yang mempunyai tujuan umum (goal) untuk meningkatkan penguasaan akademik dan ada pula struktur yang tujuannya untuk mengajarkan keterampilan sosial. Think-Pair-Share dan Numbered Heads Together adalah struktur yang dapat digunakan untuk meningkatkan penguasaan akademik, sedangkan Time Token dan Active Listening adalah struktur yang digunakan untuk mengajarkan keterampilan sosial (Nurhadi, dkk, 2004:66).

\section{Motivasi Belajar}

Motivasi merupakan kunci kesuksesan seseorang dalam berusaha atau bekerja. Seseorang yang memiliki motivasi akan mempunyai gairah atau semangat selama melakukan pekerjaan atau aktivitas tersebut. Demikian juga di dalam belajar, motivasi sangat penting untuk dimiliki oleh seorang mahasiswa. Mahasiswa yang memiliki motivasi belajar tinggi akan memiliki energi yang tinggi untuk melakukan kegiatan belajar, sehingga mahasiswa akan mempunyai gairah atau semangat selama melakukan kegiatan belajar tersebut.

Motivasi berasal dari kata "motif" yang diartikan sebagai daya upaya yang mendorong seseorang untuk melakukan sesuatu. Berawal dari kata "motif" itu, maka motivasi dapat diartikan sebagai daya penggerak yang telah menjadi aktif. Motivasi belajar dapat didefinisikan sebagai keseluruhan daya penggerak di dalam diri mahasiswa yang menimbulkan kegiatan belajar, menjamin kelangsungan kegiatan belajar mengajar, dan memberikan arah pada kegiatan belajar itu demi mencapai tujuan (Winkel, 1999:92). Menurut Purwanto (1996:71), motivasi merupakan suatu usaha yang disadari untuk mempengaruhi tingkah laku seseorang agar dia tergerak hatinya untuk bertindak melakukan sesuatu sehingga mencapai hasil dan tujuan tertentu. Pembelajaran kooperatif model Numbered Heads Together yang memiliki ciri memberikan lebih banyak waktu berpikir dan adanya interaksi antar anggota kelompok sangat memungkinkan mahasiswa saling memberi masukan untuk menyelesaikan tugas sebaik-baiknya.

Motivasi dipandang sebagai dorongan mental yang menggerakkan dan mengarahkan perilaku manusia, termasuk perilaku belajar. Motivasi mengandung adanya keinginan yang mengaktifkan, menggerakkan, menyalurkan, dan mengarahkan sikap dan perilaku individu pebelajar. Ada tiga komponen dalam motivasi yaitu kebutuhan, dorongan, dan tujuan. Dorongan merupakan kekuatan mental untuk melakukan kegiatan dalam rangka memenuhi harapan atau pencapaian tujuan. Dorongan yang berorientasi pada tujuan tersebut merupakan inti motivasi (Dimyati dan Mudjiono, 2002:81).
Sudjana (2008:160) menyimpulkan motivasi belajar mahasiswa dapat dilakukan melalui dua bentuk motivasi, yakni motivasi ekstrinsik dan motivasi instrinsik. Motivasi ekstrensik, adalah dorongan yang untuk mencapai tujuan yang datang dari luar dirinya misalnya dosen menciptakan suasana belajar yang memberi kepuasan dan kesenangan pada mahasiswa. Motivasi instrinsik adalah dorongan agar mahasiswa melakukan kegiatan belajar dengan maksud mencapai tujuan yang terkandung dalam perbuatan itu sendiri. Motivasi ini berkenaan dengan kebutuhan belajar mahasiswa sendiri. Mahasiswa harus menyadari pentingnya melakukan kegiatan belajar untuk kepuasan dan kebutuhan dirinya.. Motivasi sangat diperlukan untuk menentukan keberhasilan seseorang dalam belajar karena semakin tinggi motivasi belajar seseorang maka semakin tinggi pula tingkat keberhasilannya.

\section{Prestasi Belajar}

Sudjana dalam Jihad A dan Haris A (2008:2) berpendapat belajar adalah suatu proses yang ditandai dengan adanya perubahan pada diri seseorang, perubahan sebagai hasil proses belajar dapat ditunjukkan dalam berbagai bentuk seperti perubahan pengetahuan, pemahaman, sikap dan tingkah laku, keterampilan, kecakapan,kebiasaan serta perubahan aspek-aspek yang ada pada individu yang belajar. Setelah melalui proses belajar maka mahasiswa diharapkan dapat mencapai tujuan belajar yang disebut sebagai hasil belajar yaitu kemampuan yang dimiliki mahasiswa setelah menjalani proses belajar.

Setiap kegiatan belajar akan menghasilkan perubahan-perubahan pada diri sendiri meliputi aspek kognitif, afektif dan psikomotorik. Dalam penelitian ini ranah yang diamati adalah ranah kognitif, kemamun kognitif adalah kemampuan yang berkaitan dengan penalaran, yang meliputi enam aspek, yaitu pengetahuan, pemahaman, aplikasi, analisis, sintesisi dan evaluasi

1. Pengetahuan /Knowledge (C1)

Pengetahuan mencakup kemampuan mengenali, mengetahui dan mengingat hal-hal yang telah dipelajari dan tersimpan dalam ingatan. Pengetahuan berkenaan dengan fakta/istilah-istilah peristiwa, pengertian, kaidah, teori dan metode.

2. Pemahaman/Comprehesion (C2)

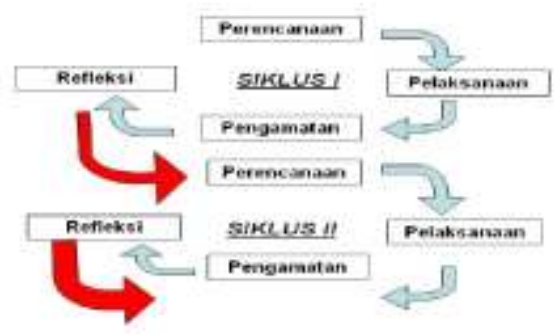

Gambar 1. Blok diagram

Pemahaman mencakup kemampuan untuk menyerap pengertian dari hal-hal yang telah dipelajari. Pada jenjang ini mahasiswa dituntut untuk mengerti dan memahami konsep yang telah dipelajari.

Kemampuan memahami terdiri dari 3 tingkatan 
a. Menterjemahkan adalah kemampuan merubah konsep abstrak menjadi suatu model simbolik untuk mempermudah orang memahaminya.

b. Menginterprestasi adalah kemampuan mengenal dan memahami ide utama suatu komunikasi, seperti gambar-gambar diagram, tabel dan grafik.

c. Mengeksplorasi adalah kemampuan menafsirkan, menarik kesimpulan berdasarkan hasil terjemahan dan interprestasi.

3. Penerapan/Aplication (C3)

Penerapan merupakan kemampuan menerapkan pengetahuan yang telah diperoleh dalam kegiatan pembelajaran untuk mengahadapi situasi baru yang ada dalam kehidupan sehari-hari.

4. Analisis/Analysis (C4)

Analisis merupakan upaya memisahkan suatu kesatuan menjadi komponen-komponen atau unsur-unsur bagian, sehingga jelas eksplisit unsurnya, meliputi unsurunsur, analisis hubungan dan analisis prinsip yang terorganisasi.

5. Sintesis/Syntesis (C5)

Sintesis adalah kemampuan menyatukan unsurunsur atau bagian menjadi satu kesatuan yang menyeluruh sintesis selalu menyatukan unsur-unsur baru, sehingga menyatukan unsur-unsur dari hasil analisis tidak dapat disebut sintesis

6. Evaluasi/Evaluation (C6)

Evaluasi merupakan kemampuan memberi keputusan tentang nilai sesuatu yang ditetapkan dengan sudut tertentu, misalnya sudut pandang tujuan, metode dan materi.

\section{METODE PENELITIAN}

\section{A. 3.1. Jenis Penelitian}

Jenis penelitian yang digunakan adalah penelitian eksperimen yang menggunakan desain Penelitian Tindakan Kelas (PTK) atau Classroom Action Recearch dengan pendekatan kualitatif. Penelitian ini dilaksanakan dalam dua siklus. Dalam setiap siklus terdiri dari perencanaan tindakan (planning), pelaksanaan tindakan (action), pengamatan (observation), dan refleksi (reflection). Keempat fase dari suatu siklus dalam sebuah PTK seperti dalam Gambar 3.1 berikut.

\section{B. Instrumen Penelitian} berikut.

Instrumen dalam penelitian ini adalah sebagai

1. Lembar Observasi Motivasi Belajar

Lembar observasi motivasi belajar mahasiswa digunakan untuk mengamati motivasi belajar mahasiswa selama mengikuti pembelajaran, yaitu dengan menggunakan pembelajaran kooperatif model Numbered Heads Together. Lembar observasi motivasi belajar berisi indikator motivasi belajar yang meliputi minat, perhatian, konsentrasi, dan ketekunan. Masing-masing sub variabel motivasi belajar terdiri dari indikator sehingga diperoleh skor untuk setiap indikator.

\section{Catatan Lapangan}

Catatan lapangan digunakan sebagai data pendukung untuk data penelitian sehingga diharapkan semua data penting dapat dikumpulkan dalam pelaksanaan penelitian ini. Catatan lapangan berfungsi untuk mencatat seluruh aktivitas yang muncul selama proses pembelajaran yang tidak dapat tercatat melalui lembar observasi, sehingga pada tahap refleksi dapat ditentukan tindakan perbaikan untuk pelaksanaan tindakan berikutnya.

\section{Tes Hasil Belajar}

Tes hasil belajar dilaksanakan pada tahap awal sebelum tindakan (Pretest)dan sesudah tindakan (Postest). Tes hasil belajar bertujuan untuk mengukur ketercapaian hasil belajar yang diperoleh mahasiswa setelah pemberian tindakan. Tes hasil belajar diberikan kepada mahasiswa dalam bentuk tes tulis yang berupa soal essay.

\section{Prosedur Pengumpulan Data}

Pengumpulan data pada penelitian ini dilakukan dengan menggunakan teknik sebagai berikut.

a. Observasi

Observasi bertujuan untuk mengamati motivasi belajar mahasiswa dalam pembelajaran kooperatif model Numbered Heads Together. Pengamatan motivasi belajar mahasiswa berdasarkan lembar observasi yang dilihat dari karakteristik minat, perhatian, konsentrasi, dan ketekunan.

b. Catatan Lapangan

Catatan lapangan digunakan sebagai data pendukung untuk data penelitian sehingga diharapkan semua data penting dapat dikumpulkan dalam penelitian ini. Data-data yang dicatat melalui catatan lapangan antara lain catatan berbagai informasi mengenai kegiatan pembelajaran yang meliputi suasana kelas, aktivitas mahasiswa, dan aktivitas dosen. Kegiatan ini digunakan untuk merekam aktivitas yang tidak bisa terekam melalui lembar observasi.

\section{c. Tes Hasil Belajar}

Tes hasil belajar dilaksanakan pada tahap awal sebelum tindakan (Pretest)dan sesudah tindakan (Postest). Tes diberikan dengan maksud untuk mengukur hasil yang diperoleh mahasiswa sebelum pemberian tindakan dan sesudah pemberian tindakan. Tes hasil belajar diberikan kepada mahasiswa dalam bentuk tes tulis yang berupa soal essay.

\section{Prosedur Penelitian}

Penelitian ini akan dilaksanakan dalam 2 siklus. Setiap siklus terdiri atas perencanaan tindakan (planning), pelaksanaan tindakan (action), observasi (observation), dan refleksi (reflection).

\section{Siklus Pertama}

\section{a. Perencanaan}

Sebelum pelaksanaan tindakan, maka perlu dilakukan perencanaan tindakan. Perencanaan tindakan dalam tahap ini adalah sebagai berikut.

1) Menyusun Rencana Pelaksanaan Perkuliahan (RPP) yang berisi tentang langkah-langkah pelaksanaan pembelajaran kooperatif model Numbered Heads Together yang akan dilakukan dalam kegiatan belajar mengajar.

2) Membuat pertanyaan-pertanyaan yang berhubungan dengan kompetensi dasar dan kegiatan belajar, disusun dalam bentuk Lembar Kerja Mahasiswa (LK). Kompetensi dasar dalam penelitian ini (siklus pertama) adalah Berbicara bahasa Inggris dengan kegiatan belajar sebagai berikut. 
a) Mahasiswa dapat mendefinisikan pengertian electrical tools

b) Mahasiswa dapat mendefinisikan pengertian function

c) Mahasiswa dapat menjelaskan principle work

d) Mahasiswa dapat menjelaskan application

3) Membuat soal tes yang akan diadakan melalui pretest, dan postes untuk mengetahui hasil belajar mahasiswa.

4) Membuat lembar observasi untuk mengukur motivasi belajar mahasiswa. Pengamatan motivasi belajar mahasiswa berdasarkan lembar observasi yang terdiri dari karakteristik minat, perhatian, konsentrasi, dan ketekunan.

5) Membuat format catatan lapangan untuk mencatat semua aktivitas dan data penting yang tidak bisa terekam/tercatat melalui lembar observasi.

6) Membentuk kelompok yang bersifat heterogen baik dari segi kemampuan akademik.

7) Memberikan penjelasan kepada mahasiswa mengenai pembelajaran kooperatif model Numbered Heads Together sebelum pelaksanaan tindakan.

b. Pelaksanaan Tindakan

Sebelum pelaksanaan tindakan pembelajaran kooperatif model NHT (Numbered Heads Together) peneliti memberikan test (Pretest) pada Mahasiswa untuk mengetahui nilai awal. Setelah itu peneliti melaksanakan tindakan sesuai dengan (RPS) Rencana Perkuliahan Semester yang telah dibuat. Pada saat pelaksanaan penelitian peneliti menjadi fasilitator selama pembelajaran, Mahasiswa dibimbing untuk belajar secara kooperatif dengan model Numbered Heads Together. Langkahlangkahnya adalah sebagai berikut.

Pertama : Numbering (penomoran); Peneliti membagi Mahasiswa ke dalam kelompok yang beranggotakan 5 Mahasiswa dan kepada masing-masing Mahasiswa diberi nomor 1 sampai 5.

Kedua : Questioning (mengajukan pertanyaan); peneliti mengajukan pertanyaan kepada Mahasiswa yang disusun dalam bentuk Lembar Kerja Mahasiswa (LK). Pertanyaan dapat bervariasi dari yang bersifat spesifik sampai pada hal yang bersifat umum. Kemudian Mahasiswa diarahkan untuk menjawab pertanyaan tersebut dengan berdiskusi bersama anggota kelompoknya.

Ketiga : Heads together (berpikir bersama); Mahasiswa menyatukan pendapatnya terhadap jawaban dari pertanyaan yang ada di LK dan meyakinkan tiap anggota dalam kelompoknya mengetahui dan memahami jawaban tersebut.

Keempat : Answering (menjawab); peneliti memanggil suatu nomor tertentu, kemudian Mahasiswa yang nomornya sesuai mengacungkan tangannya mencoba untuk menjawab pertanyan untuk seluruh kelas. Kemudian peneliti bertanya kepada Mahasiswa yang bernomor sama pada kelompok lain untuk menanggapi jawaban tersebut.
Setelah semua pertanyaan yang ada di LK terjawab, peneliti memberikan kesimpulan dari materi tersebut. peneliti memulai melakukankegiatan Pos-test, hasil dari pos-tes tersebut digunakan untuk mengetahui peningkatan prestasi belajar setelah tindakan

c. Observasi

Kegiatan ini bertujuan untuk mengamati motivasi Mahasiswa selama mengikuti proses pembelajaran kooperatif model Numbered Heads Together. Pengamatan motivasi belajar Mahasiswa berdasarkan lembar observasi yang terdiri dari karakteristik minat, perhatian, konsentrasi, dan ketekunan.

d. Refleksi

Pada tahap ini dilakukan analisis data yang telah diperoleh. Hasil analisis data yang telah ada dipergunakan untuk melakukan evaluasi terhadap proses dan hasil yang ingin dicapai. Hasil yang ingin dicapai adalah peningkatan hasil belajar Mahasiswa dalam belajar bahasa Inggris "speaking" dan adanya peningkatan motivasi mahasiswa dalam belajar melalui pembelajaran kooperatif model Numbered Heads Together.

Refleksi dimaksudkan sebagai upaya untuk mengkaji apa yang telah atau belum terjadi, apa yang dihasilkan, kenapa hal itu terjadi, dan apa yang perlu dilakukan selanjutnya. Hasil refleksi digunakan untuk menetapkan langkah selanjutnya dalam upaya menghasilkan perbaikan pada siklus kedua.

\section{Siklus Kedua}

a. Perencanaan

Sebelum pelaksanaan tindakan, maka perlu dilakukan perencanaan tindakan. Perencanaan tindakan dalam tahap ini adalah sebagai berikut.

1) Menyusun Rencana Perkuliahan Semester (RPS) yang berisi tentang langkah-langkah pelaksanaan pembelajaran kooperatif model Numbered Heads Together yang akan dilakukan dalam kegiatan belajar mengajar.

2) Membuat pertanyaan-pertanyaan yang berhubungan dengan kompetensi dasar dan kegiatan belajar, disusun dalam bentuk Lembar Kerja Mahasiswa (LK). Kompetensi dasar dalam penelitian ini (siklus kedua) adalah "speaking" dengan kegiatan belajar sebagai berikut.

a) Mahasiswa dapat menjelaskan tugas masing-masing bagian grammar

b) Mahasiswa dapat menjelaskan cara mengetahui tenses

c) Mahasiswa dapat menjelaskan langkah-langkah "vocab"

3) Membuat soal tes yang akan diadakan melalui pretest, dan postes untuk mengetahui hasil belajar mahasiswa.

4) Membuat lembar observasi untuk mengukur motivasi belajar mahasiswa. Pengamatan motivasi belajar mahasiswa berdasarkan lembar observasi yang terdiri dari karakteristik minat, perhatian, konsentrasi, dan ketekunan.

5) Membuat format catatan lapangan untuk mencatat semua aktivitas dan data penting yang tidak bisa terekam/tercatat melalui lembar observasi.

6) Membentuk kelompok yang bersifat heterogen baik dari segi kemampuan akademik. 
7) Memberikan penjelasan kepada Mahasiswa mengenai pembelajaran kooperatif model Numbered Heads Together sebelum pelaksanaan tindakan.

b. Pelaksanaan Tindakan

Sebelum pelaksanaan tindakan pembelajaran kooperatif model NHT (Numbered Heads Together) dosen memberikan test (Pretest) pada Mahasiswa untuk mengetahui nilai awal. Setelah itu dosen melaksanakan tindakan sesuai dengan Rencana Pelaksanaan Perkuliahan yang telah dibuat. Pada saat pelaksanaan penelitian dosen menjadi fasilitator selama pembelajaran, Mahasiswa dibimbing untuk belajar sesuai dengan sub kompetensi yaitu menulis di papan tulis secara kooperatif dengan model Numbered Heads Together. Langkah-langkahnya adalah sebagai berikut.

Pertama : Numbering (penomoran); peneliti membagi Mahasiswa ke dalam kelompok yang beranggotakan 5 Mahasiswa dan kepada masing-masing Mahasiswa diberi nomor 1 sampai 5.

Kedua : Questioning (mengajukan pertanyaan); peneliti mengajukan pertanyaan kepada Mahasiswa yang disusun dalam bentuk Lembar Kerja Mahasiswa (LK). Pertanyaan dapat bervariasi dari yang bersifat spesifik sampai pada hal yang bersifat umum. Kemudian Mahasiswa diarahkan untuk menjawab pertanyaan tersebut dengan berdiskusi bersama anggota kelompoknya.

Ketiga : Heads together (berpikir bersama); Mahasiswa menyatukan pendapatnya terhadap jawaban dari pertanyaan yang ada di LK dan meyakinkan tiap anggota dalam kelompoknya mengetahui dan memahami jawaban tersebut.

Keempat : Answering (menjawab); Mahasiswa memanggil suatu nomor tertentu, kemudian Mahasiswa yang nomornya sesuai mengacungkan tangannya mencoba untuk menjawab pertanyan untuk seluruh kelas. Kemudian peneliti bertanya kepada Mahasiswa yang bernomor sama pada kelompok lain untuk menanggapi jawaban tersebut.

Setelah semua pertanyaan yang ada di LK terjawab dosen memberikan kesimpulan dari materi tersebut. Dosen memulai melakukan kegiatan Postest, hasil dari postes tersebut digunkan untuk mengetahui peningkatan prestasi belajar setelah tindakan.

c. Observasi

Kegiatan ini bertujuan untuk mengamati motivasi mahasiswa selama mengikuti proses pembelajaran kooperatif model Numbered Heads Together. Pengamatan motivasi belajar mahasiswa berdasarkan lembar observasi yang terdiri dari karakteristik minat, perhatian, konsentrasi, dan ketekunan.

d. Refleksi

Pada tahap ini dilakukan analisis dan pembahasan terhadap data yang telah diperoleh. Pada akhir siklus II akan diperoleh gambaran tentang motivasi dan hasil belajar mahasiswa setelah mengalami pembelajaran kooperatif model Numbered Heads Together. Hasil pembahasan merupakan refleksi dari apa yang telah terjadi selama penerapan tindakan.

\section{E. Teknik Analisis Data}

Data yang diperoleh dalam penelitian ini berupa data kuantitaif dan data kualitatif.

\section{Data kualitatif}

Proses analisis data dimulai dengan menelaah seluruh data yang diperoleh dari hasil observasi dan catatan lapangan.

Data dalam penelitian ini akan dianalisis secara kualitatif, meliputi tiga alur yaitu reduksi data, penyajian data, dan penarikan kesimpulan (Patilima, 2005:98). Data yang diperoleh melalui perangkat pengumpulan data akan dianalisis dan selanjutnya direduksi secara sistematis berdasarkan kelompok data, data tereduksi ini selanjutnya akan disajikan secara terorganisir untuk dilakukan penarikan kesimpulan.

a. Reduksi data

Reduksi data dapat diartikan proses pemilihan, pemusatan perhatian pada penyederhanaan, pengabstrakan, dan transformasi data yang muncul dari catatan lapangan. Reduksi data merupakan bagian dari analisis yang menajamkan, menggolongkan, mengarahkan, membuang yang tidak perlu, dan mengorganisasi data dengan cara sedemikian rupa sehingga kesimpulan akhirnya dapat ditarik dan diverifikasi.

b. Penyajian data

Penyajian data dilakukan dengan mengorganisasikan data hasil reduksi dalam bentuk naratif yang memungkinkan untuk penarikan kesimpulan dan pengambilan tindakan. Sajian data selanjutnya ditafsirkan dan dievaluasi untuk merencanakan tindakan selanjutnya. Adapun hasil penafsiran dan evaluasi berupa penjelasan tentang (a) perbedaan antara rencana tindakan dan pelaksanaan, (b) persepsi peneliti, dosen pengamat, dan teman sejawat yang terlibat dalam pengamatan dan catatan lapangan terhadap tindakan yang dilakukan, (c) efek dari tindakan dan penyebabnya, (d) hambatan yang dialami dan penyebabnya, (e) perlunya perubahan dan tindakan lanjutan, dan (f) alternatif tindakan yang tepat.

c. Penarikan kesimpulan

Kegiatan ini dimaksudkan untuk memberikan kesimpulan terhadap hasil penafsiran dan evaluasi. Memverifikasi hasil kesimpulan merupakan kegiatan menguji kebenaran, kekokohan, dan kecocokan makna dari data yang diperoleh dari lapangan untuk mencapai kesimpulan yang kuat.

\section{Data kuantitatif}

a. Data motivasi belajar Mahasiswa

Data motivasi belajar mahasiswa berdasarkan aktivitas mahasiswa selama proses pembelajaran dengan menggunakan lembar observasi dihitung dengan menggunakan persentase motivasi Mahasiswa berdasarkan tiap-tiap indikator. Untuk menghitung persentase keberhasilan indikator motivasi Mahasiswa secara klasikal adalah sebagai berikut.

$\mathrm{IMk}=\frac{\sum S d}{S_{\max } \times n} \times 100 \%$ 
Keterangan:

IMk : Indikator motivasi klasikal

$\Sigma$ Sd $\quad$ : Jumlah skor yang muncul dari setiap

indikator

$\mathrm{S}_{\max } \quad$ : Skor maksimal indikator (bergantung jumlah Indikator)

n : Jumlah Mahasiswa

Berdasarkan rumus di atas akan diperoleh data tentang persentase ketercapaian masing-masing Indikator motivasi secara klasikal. Kemudian data persentase tersebut dikategorikan melalui penentuan taraf keberhasilan tindakan seperti yang terdapat pada Tabel 3.1 berikut.

Tabel 3.1. Persentase Taraf Keberhasilan Tindakan

\begin{tabular}{|c|c|c|c|}
\hline \multirow{2}{*}{ Nilaii Angka } & \multicolumn{3}{|c|}{ Nilai Mutu } \\
\cline { 2 - 4 } & Nilai Huruf & Nilai Setara & Kualifikasi \\
\hline $80<\mathrm{N} \leq 100$ & A & 4 & Sangat Baik \\
\hline $73<\mathrm{N} \leq 80$ & B+ & 3.5 & Lbh Dr Baik \\
\hline $65<\mathrm{N} \leq 73$ & B & 3 & Baik \\
\hline $60<\mathrm{N} \leq 65$ & C & 2.5 & Lbh dr. Cukup \\
\hline $50<\mathrm{N} \leq 60$ & C & 2 & Cukup \\
\hline $39<\mathrm{N} \leq 50$ & D & 1 & Kurang \\
\hline $\mathrm{N} \leq 39$ & E & 0 & Gagal \\
\hline
\end{tabular}

Kualifikasi Nilai di Polinema

Setelah data untuk masing-masing indikator selesai dihitung, akan diperoleh skor motivasi belajar berdasarkan indikator dan hasilnya dimasukkan ke dalam Tabel 3.2 berikut.

Tabel 3.2. Persentase Motivasi Belajar Siswa Berdasarkan Hasil Observasi

\begin{tabular}{cccc} 
& Skor & \multicolumn{2}{c}{ Kategori } \\
\cline { 3 - 4 } Indikator & $\begin{array}{c}\text { Motivasi } \\
\text { Motivasi }\end{array}$ & $\begin{array}{c}\text { Taraf } \\
\text { Keberhasilan }\end{array}$ & $\begin{array}{c}\text { Nilai } \\
\text { dengan } \\
\text { Huruf }\end{array}$ \\
\hline Minat & & &
\end{tabular}

Perhatian

Konsentrasi

Ketekunan

\section{Rata-rata}

Data motivasi belajar siswa secara umum diperoleh dari skor motivasi untuk tiap-tiap indikator motivasi klasikal (\%) yang dijumlahkan kemudian dibagi dengan banyaknya indikator motivasi.

$$
\mathrm{MB}=\frac{\sum I M k}{n}
$$

Keterangan:

MB : Motivasi Belajar Mahasiswa

¿IMk : Jumlah Skor Indikator Motivasi Klasikal

\section{n : Jumlah Indikator Motivasi Klasikal}

b. Data hasil belajar Mahasiswa

Analisis untuk mengetahui hasil belajar Mahasiswa ditentukan dengan menganalisis menggunakan pre-test (menggunakan metode konvensional) dan post-test one group (menggunakan metode Numbered Head Together) dengan rumus

$$
t=\frac{M d}{\sqrt{\frac{\sum x^{2} d}{N(N-1)}}}
$$

Keterangan: Md = Mean dari perbedaan pre test, post test

$\mathrm{Xd} \quad=$ Deviasi masing-masing subjek $(\mathrm{d}-$ $\mathrm{Md})$

$\sum x^{2} d=$ Jumlah kuadrat deviasi

$\mathrm{N} \quad=$ Subjek pada sample

d.b. $=$ Ditentukan dengan $\mathrm{N}-1$

(Arikunto 2006:306)

\section{F. 3.6 Indikator Keberhasilan Tindakan}

Indikator keberhasilan tindakan dapat diketahui dengan membandingkan skor motivasi dan hasil belajar pada siklus I dan siklus II seperti pada Tabel 3.3 berikut.

Tabel 3.3. Indikator Keberhasilan Tindakan

\begin{tabular}{cccc}
\hline $\begin{array}{c}\text { Elemen yang } \\
\text { diteliti }\end{array}$ & Siklus I & Siklus II & keberhasilan \\
\hline $\begin{array}{c}\text { Motivasi } \\
\text { Belajar }\end{array}$ & $\mathrm{MB}_{\mathrm{I}}$ & $\mathrm{MB}_{\mathrm{II}}$ & $\mathrm{MB}_{\mathrm{II}}>\mathrm{MB}_{\mathrm{I}}$ \\
\hline Hasil Belajar & $\mathrm{HB}_{\mathrm{I}}$ & $\mathrm{HB}_{\mathrm{II}}$ & $\mathrm{HB}_{\mathrm{II}}>\mathrm{HB}_{\mathrm{I}}$ \\
\hline
\end{tabular}

\section{DATA HASIL PENELITIAN}

\section{A. Siklus pertama}

Data motivasi belajar mahasiswa diperoleh dari lembar observasi motivasi belajar mahasiswa yang telah disediakan oleh peneliti dan telah diisi oleh observer. Secara ringkas data hasil observasi terhadap motivasi belajar mahasiswa pada siklus ini (pertama) yang meliputi minat, konsentrasi, perhatian, dan ketekunan disajikan dalam Tabel 4.2 berikut:

Tabel 4.1 Persentase Motivasi Belajar mahasiswa teknik listrik Berdasarkan Hasil Observasi pada Siklus Pertama

\begin{tabular}{llll}
\hline & Skor & Kategori & \\
\cline { 3 - 4 } Indikator & Motivas & & Nilai \\
Motivasi & $\mathrm{i}$ & Taraf Keberhasilan & $\begin{array}{l}\text { dengan } \\
\text { Huruf }\end{array}$ \\
\hline Minat & 57.33 & Cukup & $\mathrm{C}$ \\
\hline Konsentrasi & 62.67 & Lebih dari cukup & $\mathrm{C}+$ \\
\hline Perhatian & 56 & Cukup & $\mathrm{C}$ \\
\hline Ketekunan & 69.33 & baik & $\mathrm{B}$ \\
\hline Rata-rata & 61.33 & Lebih dari cukup & $\mathrm{C}+$ \\
\hline
\end{tabular}

Tabel 4.2 Kualifikasi Nilai di Polinema

\begin{tabular}{|c|c|c|c|}
\hline \multirow{2}{*}{ Nilaii Angka } & \multicolumn{3}{|c|}{ Nilai Mutu } \\
\cline { 2 - 4 } & Nilai Huruf & Nilai Setara & Kualifikasi \\
\hline $80<\mathrm{N} \leq 100$ & A & 4 & Sangat Baik \\
\hline $73<\mathrm{N} \leq 80$ & B+ & 3.5 & Lbh Dr Baik \\
\hline $65<\mathrm{N} \leq 73$ & B & 3 & Baik \\
\hline $60<\mathrm{N} \leq 65$ & $\mathrm{C}+$ & 2.5 & Lbh dr. Cukup \\
\hline $50<\mathrm{N} \leq 60$ & $\mathrm{C}$ & 2 & Cukup \\
\hline $39<\mathrm{N} \leq 50$ & D & 1 & Kurang \\
\hline
\end{tabular}




\begin{tabular}{|l|l|l|l|}
\hline $\mathrm{N} \leq 39$ & $\mathrm{E}$ & 0 & Gagal \\
\hline
\end{tabular}

Berdasarkan Tabel 4.2 di atas dapat diketahui bahwa berdasarkan kualifikasi yang telah ditentukan Polinema serta rata-rata motivasi belajar mahasiswa berdasarkan hasil observasi pada siklus pertama sebesar $61.33 \%$ termasuk Kualifikasi Lebih dari cukup. Sedangkan motivasi belajar mahasiswa Indikator minat sebesar $57.33 \%$ termasuk dalam Kualifikasi Cukup, 2) Indikator konsentrasi sebesar 62,67 termasuk Kualifikasi lebih dari cukup 3) Indikator perhatian sebesar $56 \%$ termasuk Kualifikasi cukup, dan 4) Indikator ketekunan sebesar $69.33 \%$ termasuk Kualifikasi baik.

\section{B. Hasil Belajar Mahasiswa dalam Pembelajaran Kooperatif Model Numbered Heads Together}

Perbedaan hasil test antara pre-test dengan post-test adalah t hitung $1,10<\mathrm{t}$ tabel 2,04 sehingga perlakuan yang diberikan pada siklus pertama tidak menyebabkan peningkatan hasil belajar atau tidak signifikan.

\section{Siklus kedua}

Data motivasi belajar mahasiswa diperoleh dari lembar observasi motivasi belajar mahasiswa yang telah disediakan oleh dosen dan telah diisi oleh observer. Secara ringkas data hasil observasi terhadap motivasi belajar mahasiswa pada siklus II yang meliputi minat, perhatian, konsentrasi, dan ketekunan disajikan dalam Tabel 4.4 berikut.

Tabel 4.3. Persentase Motivasi Belajar mahaSiswa D42B Berdasarkan Hasil Observasi pada Siklus II

\begin{tabular}{|c|c|c|c|}
\hline \multirow{2}{*}{$\begin{array}{l}\text { Indikator } \\
\text { Motivasi }\end{array}$} & \multirow{2}{*}{$\begin{array}{l}\text { Skor } \\
\text { Motivasi } \\
(\%)\end{array}$} & \multicolumn{2}{|l|}{ Kategori } \\
\hline & & $\begin{array}{l}\text { Taraf } \\
\text { Keberhasilan }\end{array}$ & $\begin{array}{l}\text { Nilai dengan } \\
\text { Huruf }\end{array}$ \\
\hline Minat & 88 & Sangat baik & $\mathrm{A}$ \\
\hline Konsentrasi & 92 & Sangat baik & $\mathrm{A}$ \\
\hline Perhatian & 85,33 & Sangat baik & $\mathrm{A}$ \\
\hline Ketekunan & 84 & Sangat baik & $\mathrm{A}$ \\
\hline Rata-rata & 87,33 & Sangat baik & $\mathrm{A}$ \\
\hline
\end{tabular}

Berdasarkan Tabel 4.3 di atas dapat diketahui bahwa rata-rata motivasi belajar mahasiswa berdasarkan hasil observasi pada siklus II sebesar $\mathbf{8 7 , 3 3} \%$ dengan taraf keberhasilan termasuk dalam kategori sangat baik. Sedangkan motivasi belajar mahasiswa per indikator motivasi yaitu: 1) Indikator minat sebesar $88 \%$ dengan taraf keberhasilan termasuk dalam kategori sangat baik, 2) Indikator perhatian sebesar $92 \%$ dengan taraf keberhasilan termasuk dalam kategori sangat baik, 3) Indikator konsentrasi sebesar 85,33\% dengan taraf keberhasilan termasuk dalam kategori sangat baik, dan 4) Indikator ketekunan sebesar $84 \%$ dengan taraf keberhasilan termasuk dalam kategori sangat baik.

Tes hasil belajar mahasiswa pada siklus II dilaksanakan pada bulan Mei 2019 dan diikuti oleh seluruh mahasiswa kelas D4 2B (25 mahasiswa) didapatkan hasil perbedaan antara pre-test dengan post-test adalah t hitung $11,38>\mathrm{t}$ tabel 2,04, sehingga perlakuan yang diberikan pada siklus kedua mengalami peningkatan atau signifikan.

\section{Perbandingan Siklus pertama dan Siklus kedua}

\section{Motivasi Belajar}

Berdasarkan hasil penelitian pada pelaksanaan pembelajaran kooperatif model Numbered Heads Together pada siklus pertama dan siklus kedua iketahui bahwa motivasi belajar mahasiswa mengalami peningkatan. Perbandingan motivasi belajar pada siklus pertama dan siklus kedua disajikan dalam Tabel 4.5 berikut:

Tabel 4.4. Perbandingan Motivasi Belajar Siswa pada Siklus I dan Siklus II

\begin{tabular}{llll}
\hline $\begin{array}{l}\text { Indikator } \\
\text { motivasi }\end{array}$ & $\mathbf{M B}_{\mathbf{I}}(\boldsymbol{\%})$ & $\mathbf{M B}_{\mathbf{I I}}(\boldsymbol{\%})$ & $\begin{array}{l}\text { Peningkatan } \\
(\boldsymbol{\%})\end{array}$ \\
\hline Minat & 57.33 & 88 & 30,67 \\
\hline Konsentrasi & 62.67 & 92 & 29,33 \\
\hline Perhatian & 56 & 85,33 & 29,33 \\
\hline Ketekunan & 69.33 & 84 & 14,67 \\
\hline Rata-rata & $\mathbf{6 1 . 3 3}$ & $\mathbf{8 7 , 3 3}$ & $\mathbf{2 6}$ \\
\hline Ketrangan: & & &
\end{tabular}

Keterangan:

$\mathrm{MB}_{\mathrm{I}}$ : motivasi belajar siklus pertama

$\mathrm{MB}_{\mathrm{II}}$ : motivasi belajar siklus kedua

Berdasarkan Tabel 4.4 di atas, dapat diketahui bahwa motivasi belajar mahasiswa pada siklus II mengalami peningkatan sebesar $26 \%$ dibandingkan dengan motivasi belajar mahasiswa pada siklus pertama. Motivasi belajar mahasiswa pada setiap indikator juga mengalami peningkatan, yaitu indikator minat mengalami peningkatan sebesar 30,67\%, indikator konsentrasi mengalami peningkatan sebesar $29,33 \%$, indikator perhatian mengalami peningkatan sebesar 29,33\%, dan indikator ketekunan mengalami peningkatan sebesar $14,67 \%$.

\section{E. Indikator Keberhasilan Tindakan}

Tabel 4.5. Indikator Keberhasilan Tindakan

\begin{tabular}{llll}
\hline $\begin{array}{l}\text { Elemen yang } \\
\text { diteliti }\end{array}$ & $\begin{array}{l}\text { Siklus } \\
\text { pertama }\end{array}$ & $\begin{array}{l}\text { Siklus } \\
\text { kedua }\end{array}$ & keberhasilan \\
\hline $\begin{array}{l}\text { Motivasi } \\
\text { Belajar }\end{array}$ & 61,33 & 87,33 & $87,33>61,33$ \\
\hline Hasil Belajar & 1,10 & 11,38 & $11,38>1,10$ \\
\hline
\end{tabular}

\section{F. Motivasi Belajar Siswa}

Keberhasilan dalam belajar ditentukan seberapa kuat seorang mahasiswa memiliki motivasi yang kuat dalam belajarnya. Tanpa motivasi yang kuat, hasil belajar mahasiwa kurang maksimal. Motivasi belajar ini bisa diwujudkan dengan adanya karakteristik tingkah laku yang meliputi aspek minat, konsentrasi, perhatian, dan ketekunan.

Analisis data menunjukkan bahwa minat mahasiswa cenderung meningkat setelah pembelajaran kooperatif model Numbered Heads Together. Dengan metode ini terlihatlah hasil pada siklus pertama sebesar $61,33 \%$ yang termasuk pada kualifikasi nilai lebih dari cukup, sedangkan pada siklus kedua menunjukkan taraf keberhasilan sebesar $87,33 \%$ yang termasuk ke dalam kualifikasi nilai sangat baik. Sejalan adanya peningkatan persentase kenaikan nilai sebesar $26 \%$ setelah diberikan pembelajaran kooperatif model Numbered Heads Together, maka pemberian metode ini menunjukkan adanya peningkatan keberhasilan yang signifikan. Singkat kata, mahasiswa akan memiliki minat sebanding dengan hubungan antara kebutuhan mahasiswa dan materi kuliahnya. 
Pada siklus pertama komponen minat menunjukkan taraf keberhasilan sebesar $57,33 \%$ yang termasuk dalam kualifikasi lebih dari cukup, hal tersebut dikarenakan sebagian dari mereka masih belum berminat dalam belajar dengan metode ini.

Berdasarkan analisis data, konsentrasi mahasiswa yang mengalami pembelajaran kooperatif model Numbered Heads Together pada siklus pertama menunjukkan taraf keberhasilan sebesar $62,67 \%$ dengan kualifikasi lebih dari cukup, sedangkan pada siklus kedua menunjukkan taraf keberhasilan sebesar $92 \%$ dengan kualifikasi sangat baik.

Berdasarkan rumus persentase peningkatan motivasi menunjukkan bahwa konsentrasi mahasiswa mengalami persentase peningkatan sebesar $29,33 \%$ setelah diberi pembelajaran kooperatif model Numbered Heads Together.

Berdasarkan analisis data, perhatian mahasiswa yang mengalami pembelajaran dengan menggunakan pembelajaran kooperatif model Numbered Heads Together menunjukkan taraf keberhasilan pada siklus pertama sebesar 56\% dengan kualifikasi lebih dari cukup, sedangkan pada siklus kedua menunjukkan taraf keberhasilan sebesar $85,33 \%$ yang termasuk dalam kualifikasi sangat baik.

Berdasarkan analisis data, ketekunan mahasiswa yang mengalami pembelajaran kooperatif model Numbered Heads Together pada siklus pertama menunjukkan taraf keberhasilan sebesar $69,33 \%$ dengan kualifikasi baik, sedangkan pada siklus kedua menunjukkan taraf keberhasilan sebesar $84 \%$ yang termasuk dalam kualifikasi sangat baik. Berdasarkan rumus persentase peningkatan motivasi menunjukkan bahwa ketekunan mahasiswa mengalami persentase peningkatan sebesar $14,67 \%$ setelah mengalami pembelajaran kooperatif model Numbered Heads Together.

Pada siklus pertama ketekunan mahasiswa masih termasuk dalam kualifikasi lebih dari cukup (69,33\%), hal itu karena mahasiswa belum akrab dengan pembelajaran kooperatif berdasarkan tujuannya secara baik. Upaya yang bisa diberikan menata susunan tempat duduk sehingga mereka bisa saling komunikatif antara satu dengan lainnya dengan cara menunjukkan kelebihan dari menggunakan metode ini baik dilihat dari tujuan dan manfatnya. Terbukti unsur ketekunan mahasiswa mengalami peningkatan dan termasuk dalam kualifikasi sangat baik (84\%).

Berdasarkan analisis data motivasi mahasiswa secara umum, motivasi mereka setelah diberi pembelajaran kooperatif model Numbered Heads Together menunjukkan persentase peningkatan sebesar $26 \%$, yaitu pada siklus pertama sebesar $61,33 \%$ dengan kualifikasi lebih dari cukup meningkat menjadi $87,33 \%$ pada siklus kedua dengan kualifikasi sangat baik.

Pada siklus kedua, mahasiswa sudah mampu mendalami tujuan dan maksud dengan pembelajaran kooperatif model Numbered Heads Together. Buktinya terdapat peningkatan setiap unsur motivasi belajar dimana aspek perhatian dan ketekunan mengalami persentase peningkatan yang cukup besar yaitu diatas $25 \%$ minat (30,67\%), konsentrasi (29,33\%), perhatian $29.33 \%$, sedangkan unsur ketekunan mengalami peningkatan sebesar $(14,67 \%)$

\section{G. Hasil Belajar Siswa}

Berdasarkan hasil analisis prestasi belajar siklus pertama diperoleh data yaitu $t_{\text {hitung }}=1,10$ dan $t_{\text {tabel }}=11.38$. Dengan demikian $t_{\text {hitung }}<t_{\text {tabel }}$, sehingga perlakuan pembelajaran kooperatif model Numbered Heads Together yang diterapkan pada siklus pertama tidak menyebabkan peningkatan hasil belajar atau tidak signifikan. Beberapa hal yang menyebabkan tidak tercapainya ketuntasan belajar pada siklus pertama antara lain sebagian besar mahasiswa tidak memusatkan perhatian atau tidak memperhatikan ketika ada temannya menjawab pertanyaan yang ada di Lembar kerja serta mahasiswa kurang aktif dalam bekerja sama/berdiskusi di dalam kelompoknya. Pada siklus pertama, tercatat hanya $56 \%$ mahasiswa yang memusatkan perhatian atau memperhatikan kepada temannya yang sedang menjawab pertanyaan yang ada di Lembar kerja. Sedangkan mahasiswa yang aktif dalam bekerja sama/berdiskusi di dalam kelompoknya hanya $57,33 \%$.

Berdasarkan hasil analisis prestasi belajar siklus II diperoleh data yaitu $t_{\text {hitung }}=11,38$ dan $t_{\text {tabel }}=1.10$. Dengan demikian $t_{\text {hitung }}>t_{\text {tabel }}$, sehingga perlakuan pembelajaran kooperatif model Numbered Heads Together yang diterapkan pada siklus kedua menyebabkan peningkatan hasil belajar atau signifikan.

\section{KESIMPULAN}

Berdasarkan penyajian data, temuan, maka ditarik kesimpulan: Penerapan pembelajaran kooperatif model Numbered Heads Together dapat meningkatkan motivasi (minat, perhatian, konsentrasi, dan ketekunan) dan hasil belajar mata kuliah bahasa Inggris Teknik Polinema. Motivasi mahasiswa setelah mengalami pembelajaran kooperatif model Numbered Heads Together menunjukkan persentase peningkatan sebesar $26 \%$.

\section{DAFTAR PUSTAKA}

[1] Arikunto, S. 2006. Prosedur Penelitian Suatu Pendekatan Praktik. Jakarta: PT Rineka Cipta.

[2] Dimyati dan Mudjiono. 2002. Belajar dan Pembelajaran. Jakarta: Rineka Cipta.

[3] Jihad, A; Haris A. 2008. Evaluasi Pembelajaran. Jakarta: Multi Presindo

[4] Lie, A. 2005. Cooperative Learning. Jakarta: PT. Gramedia Widiasarana Indonesia.

[5] Lutfiana, Y. 2006. Upaya Peningkatan Motivasi dan Prestasi Belajar Biologi Siswa SMP Negeri 6 Pasuruan Kelas II-C melalui Penerapan Pembelajaran Kooperatif Model Numbered Heads Together dalam Pokok Bahasan Sistem Indera pada Manusia. Skripsi tidak diterbitkan. Malang: FMIPA UM.

[6] Nurhadi; Burhan, Y; Senduk, AG. 2004. Pembelajaran Kontekstual dan Penerapannya dalam KBK. Malang: Universitas Negeri Malang.

[7] Prayitno, E. 1989. Motivasi dalam Belajar. Jakarta: Proyek Pengembangan Lembaga Pendidikan Tenaga Kependidikan.

[8] Purwanto, N. 1996. Psikologi Pendidikan. Bandung: Remaja Rosda Karya.

[9] Slavin, R. E. 1995. Cooperative Learning, Second Edition. Boston: Allyn and Bacon.

[10] Sudjana, N. 2005. Penilaian Hasil Proses Belajar Mengajar. Bandung: PT. Remaja Rosdakarya. 